\title{
Images et objets : la tuberculose et les rayons X
}

\section{Bernike Pasveer}

\section{CpenEdition}

Journals

Édition électronique

URL : https://journals.openedition.org/tc/498

DOI : $10.4000 /$ tc. 498

ISSN : 1952-420X

\section{Éditeur}

Éditions de l'EHESS

\section{Édition imprimée}

Date de publication : 1 mars 1996

ISSN : 0248-6016

\section{Référence électronique}

Bernike Pasveer, «Images et objets : la tuberculose et les rayons X», Techniques \& Culture [En ligne], 25-26 | 1996, mis en ligne le 28 octobre 2005, consulté le 29 septembre 2022. URL : http:// journals.openedition.org/tc/498; DOI : https://doi.org/10.4000/tc.498

Ce document a été généré automatiquement le 29 septembre 2022

Tous droits réservés 


\title{
Images et objets : la tuberculose et les rayons $\mathrm{X}$
}

\author{
Bernike Pasveer
}

